DE DE GRUYTER OPEN
Journal of Intercultural Management

Vol. 9 | No. 4 | December 2017 | pp. 21-30

DOI 10.1515/joim-2017-0018

\title{
Iryna Stavytska
}

National Technical University of Ukraine

Igor Sikorsky Kyiv Polytechnic Institute

iryna_stavytska@ukr.net

\section{Modern Tendencies in Foreign Language Teaching}

\section{ABSTRACT}

Objective: The purpose of the article is to study current trends in the field of language policy. Methodology: Analysis of normative documents concerning the teaching of foreign languages in the European Union

Findings: The main trends of language policy are life-long learning, students' mobility, multilingualism, using English as lingua franca, the use of information and communication technologies for the formation of foreign language competence.

Value Added: Analysis of the current trends in the development of foreign language competence in higher education.

Recommendations: The study of world trends in the training of specialists in general and language policy in particular.

Key words: competence, distance learning, mobility, multilingualism, blended learning, foreign language, mobility

JEL codes: $123, \mathrm{Z} 13, \mathrm{D} 83$ 


\section{Introduction}

Modern conditions of the development of society change the requirements for the professional training of future specialists. A huge attention should be paid to the study of world trends in the training of specialists in general and language policy in particular.

Learning a foreign language is a key aspect of training future professionals who can be competitive in achieving their professional goals. That is why the foreign experience of teaching foreign languages is very important.

On the basis of analysis of the concept and structure of foreign language competence of professionals in different areas, it is established that in modern pedagogical literature there is no common understanding of the essence of foreign language competence, which is a complex and multifaceted scientific concept. Moreover, foreign language competence is also a dynamic combination of knowledge and practical skills. It determines the ability of individuals to successfully use a foreign language in professional, scientific activities and in social communication (Stavytska, 2017).

European countries pay more attention to developing foreign language skills. There are currently 24 official languages in the European Union (Foreign language learning statistics, 2017). In high school, 59\% of students study two or more foreign languages. In Luxembourg, France, the Czech Republic, Romania, Finland and Slovakia, two foreign languages are taught in schools. In European countries, students learn English (96\%), French (23\%), Spanish (22\%), German (19\%), Italian (3\%) and Russian (2\%).

Luxembourg has three official languages: Luxemburg, German and French. Students learn them in elementary school, and English is studied in high school.

In the countries of Eastern and Northern Europe, which joined the European Union in 2004 or 2007, the Russian was previously the main foreign language. The percentage of English learners increased significantly: more than 50\% were studying English in 2015. In Estonia, Lithuania, the Czech 
Republic, Bulgaria, Slovakia, Romania, and Latvia, it ranged from 69\% to 86\% in 2015 and more than 90\% in Poland and Croatia.

In Sweden, in 2003, the government allowed municipalities to launch pilot projects, where English is used as a language of instruction in elementary and secondary schools. Half of all subjects are taught in a foreign language. The results of the experiment in 2010 showed a better command of the foreign language, and even higher students' satisfaction. Starting in 2011, any school may apply to the School Inspectorate for the use of English as a language of instruction. In Sweden, a system of additional points is introduced for learning a foreign language that influences entry into higher education. Learning of a second foreign language is encouraged.

The purpose of the article is to study current trends in the field of language policy, to conduct the analysis of normative documents concerning the teaching of foreign languages in the European Union.

Internationalization of universities has been developing rapidly. Universities expand programmes for foreign entrants, build a team who can teach a foreign language, develop international programmes for cooperation with other universities.

English language as lingua franca. One of the most important aspects of the process of modern globalization is the role of English as a universal language. English language becomes the language of international communication, its knowledge is a prerequisite for the qualitative performance of professional duties. The number of people studying English around the world increases every year. English becomes a universal communication tool as a second foreign language, as its conversance gives economic, social and political advantages.

The mobility of students. According to European standards, students' mobility is now playing an important role. There are many international programmes that enable students to gain foreign experience and increase their foreign language proficiency. Among the most famous programmes are Fulbright Graduate Student Program, DAAD, Erasmus Mundus Program, and others. More and more students are studying abroad. Almost 5 mil- 
lion of them studied in another country in 2014, while in 2000 this number was 2.1 million students.

Political and demographic changes continue to formulate state policy towards foreign students. For example, in Asia, there is a special programme to encourage students to study in their own countries, and not to join western universities, that is why "Common Space of Higher Education" has been created to encourage student trans-border mobility and academic integration throughout Southeast Asia.

Studying abroad, international experience is valued by employers around the world. Students expand their outlook, learn how to communicate in the international community, develop their decision-making skills. The report of the European Commission "Effects of mobility on the skills and employability of students and the internationalization of higher education institutions" (Brandenburg, 2014) has shown that there is a quantitative evidence illustrating the positive impact of mobility on further employment, autonomy, and career development.

The geography of international campuses is also expanding. In recent decades, numerous universities have opened their branches abroad. The most famous is Nottingham's campus in Ningbo, a branch of the University of China and a branch of the New York University in Abu Dhabi. In total, there are almost 220 affiliates around the world. Branches are created for foreign students who are not able to travel to Europe or the United States.

Over the past six years, a significant number of well-known American, Australian and British international campuses have ceased their activities. In most cases, closure has been linked to economic and political changes, or to the reduction in the number of entrants.

Using technologies for studying. Technologies are essential for the process of teaching in higher education. Information technology is becoming a key factor both in economic competitiveness and social development. Opened Online Courses (MOOCs) have become one of the most professional aspects of technology use in recent years. More than 142 universities offer free courses for all participants through Coursera and edX. Nevertheless, 
there are certain disadvantages of learning with the use of online courses. A study conducted in 2013 explained that only about 5\% of students completed coursework at Coursera online. The study covered seventeen courses.

Distributed learning systems such as ATutor, ILIAS, Dokeos, LON-CAPA, OpenUSS, Sakai, Spaghettilearnin, dotLRN have become widespread. Based on the comparative analysis of e-learning systems, it is concluded that the Moodle system has many advantages, which is why it has become the most popular in the world. It is expedient to use the Moodle system for the formation of students' foreign language competence, since there are many available tools: wiki, glossary, blogs, forums, chats, etc. The use of video and audio materials, graphic information or drawings greatly increases the effectiveness of teaching and the interest of students in the acquisition of new material. Webinars, which enable the exchange of information between the teacher and the students through the virtual class, also started to be more common.

Virtual learning environments, flipped classrooms and blended learning are widely used. The "flipped classrooms" method offers a combination of online and offline classroom teaching. Students learn material at home, and discuss the revised information in the classroom. The application of these new methods and technologies proves the effectiveness of teaching.

The technology provides researchers with new tools for collecting, analyzing and disseminating data. Libraries were able to digitize a large number of rare books and manuscripts. For example, the British Library digitized many of its manuscript collections. The European Commission funds the new European Internet portal, which gives an access to a great deal of books, paintings, films, museum objects and archival records from European libraries and archives. Originally launched in 2010 with 4.5 million objects, the portal continues to grow and improve itself. An open access provides significant benefits to scientists, who can quickly get necessary information about the latest world achievements and developments.

Many programs for the development of linguistic diversity and in-depth study of foreign languages have been developed (Languages for Europe, 2007). 
CMC - Language learning for university students

DissMark

EBAFLS - Tools for assessing foreign language skills

EU \& I (European Awareness and Intercomprehension)

L'Europe ensemble

FEEL (Funny, easy and effective learning about countries, cultures and languages

JOYFLL - Join your grandchildren in foreign language learning

Learning by moving - Language learning on public transport

Lingoland - The European platform for children on the Internet

Lingu@net Europa - Help and advice for language learners

The projects such as Erasmus+ are aimed at increasing the level of foreign language skills. The Council of Europe has established the European Day of Languages which is held annually on September 26 (it started in 2001). The purpose of the holiday is an educational campaign on the importance of learning foreign languages.

The eTwinning Internet platform allows foreign language teachers to collaborate, create collaborative projects, and so on.

Multilingualism. Implementation of the provisions of the Bologna Process, the development of the European Higher Education Area (EHEA) is impossible without language skills. That is why linguistic diversity and multilingualism are essential principles for ensuring the quality of education in Europe. Common European Framework of Reference for Languages states that multilingualism is the knowledge of a certain number of languages or the coexistence of different languages in a particular society. Multilingualism can be achieved through the simple diversification of languages offered for studying in a separate school or educational system, or by encouraging students to learn more than one foreign language, or, moreover, by diminishing the dominant role of English as a means of international communication. Council of Europe developed Resolution on the European Strategy for Multilingualism where the importance of multilingualism for social inclusion, intercultural dialogue and 
the development of the European Community is described. Multilingualism is a factor contributing to the competitiveness of the European economy, mobility and job application (Council Resolution, 2008).

One of the key documents supporting linguistic diversity in Europe is the European Charter for Regional or Minority Languages. The Charter is a convention which, on the one hand, is designed to protect and promote the development of regional languages as an aspect of Europe's cultural heritage, and on the other hand, it aims to create conditions for the use of regional languages. For studying language policy in the field of higher education, data was collected in 69 largest educational institutions from 67 cities-participants in Europe. According to the results of the study, it is established that:

- English, French, German and Spanish take the leading place among the foreign languages.

- 62 out of 69 analyzed institutions teach foreign languages. 15 schools teach more than 4 languages. 25 institutions teach the languages of national minorities. Immigrant languages are taught only in 4 institutions.

- International mobility of students and teachers has led to the fact that English is the second language in many European universities. A large number of textbooks are written in English.

- Universities make a lot of effort to attract as many foreign students as possible.

- European universities are financially supporting student mobility, but only 10 of the surveyed universities have made mobility programmes binding on students of philology (Multilingual Europe, 2012).

Modern trends are aimed at gaining knowledge, improving skills throughout the life cycle. The main provisions of this principle are reflected in the European Qualifications Framework for Lifelong Learning. The main objectives of the programme are to provide mobility for students and employees, and opportunities for lifelong learning (The European Qualifications Framework, 2008). 


\section{Conclusion}

A lot of new programmes and documents are provided in Europe for the development of language learning. On the basis of these documents some conclusions can be made.

- The priority is to support higher education institutions under the Erasmus+ programme to improve the effectiveness of educational reforms.

- Multilingualism is quite important. Students should study several foreign languages.

- There is a need to develop mobility programmes for students and teachers.

- It is necessary to combine learning with the use of the information and communication technologies.

- Teachers of higher educational establishments should know how to use modern technologies, undergo advanced training, etc.

- Higher education institutions should strive for an open access to the educational resources.

Internationalization of education has benefits, among which are the strengthening of the economy, poverty reduction and increase of the investments. Internationalization of education improves the quality of higher education.

The article analyzes the current trends in the development of foreign language competence in higher education. It is determined that the main trends in language policy in the European educational space are: mobility of students, multilingualism, understanding of English language as lingua franca, the use of ICT for the formation of foreign language competence. 


\section{References}

Brandenburg, U. (2014). Effects of mobility on the skills and employability of students and the internationalization of higher education institutions [online], http://ec.europa. eu/dgs/education_culture/repository/ education/library/study/2014/erasmus-impact_en.pdf, access: 22 Jan. 2017.

Council Resolution on a European strategy for multilingualism (2008). [online], http:// www.consilium.europa.eu/ueDocs/cms_Data/docs/pressData/en/educ/104230. pdf, access 22 Jan. 2017.

First European Survey on Language Competences. Final Report (2004). [online], http:// ec.europa.eu/languages/library/studies/executive-summary-eslc_en.pdf, access 22 Jan. 2017.

Foreign language learning statistics (2017). Eurostat [online], http://ec.europa.eu/ eurostat/statisticsexplained/index.php/Foreign_language_learning_statistics, access 22 Jan. 2017.

Languages for Europe: 30 projects for promoting language learning (2007). Luxembourg. OOPEC.

Multilingual Europe: trends in the policies and practices of multilingualism in Europe (2012). Kyiv. Lenvit.

Report to the European Commission on New modes of learning and teaching in higher education (2014) Luxembourg. Publications Office of the European Union.

Stavytska, I. (2017). The formation of foreign language competence of engineering students by means of multimedia. Advanced Education, No 7, pp. 123-128. DOl: 10.20535/2410-8286.95301. 
The European Qualifications Framework for Lifelong Learning (2008). Luxembourg. Office for Official Publications of the European Communities. 